\title{
The evolution of the support scheme for promoting renewable energy sources in Romania
}

\author{
Pavel Atănăsoae*, Radu Pentiuc, Crenguţa Bobric, and Eugen Hopulele \\ Faculty of Electrical Engineering and Computer Science, Stefan cel Mare University, Suceava 720229, Romania
}

\begin{abstract}
The paper presents an analysis of the evolution of the support scheme for promoting renewable energy sources in Romania, following: the annual mandatory quotas of green certificate purchase and those achieved; the price of green certificates; the evolution of the RES-E installed capacity and implicitly of the investments in renewable energy sources; the structure of the installed power in RES-E (wind power plants, photovoltaic power plants, hydroelectric power plants with an installed capacity that is not larger than $10 \mathrm{MW}$, biomass power plants); the contribution of the renewable energy sources to the production of electricity in Romania.
\end{abstract}

\section{Introduction}

The investments in renewable energy sources (RES) are much higher than in technologies using fossil fuels. For this reason, the Member States of the European Union (EU) have adopted a series of measures for encouraging investment in renewable energy sources and for achieving the European objective: $20 \%$ of the power generated by the year 2020 in the European Union must come from renewable energy sources (Directive 2009/28/EC).

As for operating support, two major sub-categories are to be distinguished: price-based support and quantitybased support [1-5]. From a more practical point of view, the crucial difference between the support schemes different is the degree to which the investor's revenue is exposed to the volatility of market prices and, hence, the market risk involved.

The fixed "feed-in tariff" systems [6] were adopted by Germany in year 2000 and were taken by countries such as France, Denmark, Spain, Italy, Czech Republic and Great Britain (in Great Britain, this system is used only for electricity used for domestic activities). The system consists of the acquisition made by producers, suppliers or consumers, of electricity produced from renewable energy sources at a fixed price (feed-in tariff), whose value is determined according to the used renewable source and the amount of energy produced.

The mandatory quotas system and green certificates $[7,8]$ are used in countries like Great Britain, Romania, Sweden, Belgium, Italy and Poland.

The mandatory quotas system is a mechanism for promoting the production of electrical energy from renewable energy sources by purchasing the suppliers of

\footnotetext{
* e-mail: atanasoae@eed.usv.ro
}

mandatory quotas of electrical energy generated from these sources for sale to consumers. The purchase price is determined on a competitive basis.

\section{The evolution of the installed power in RES-E in Romania}

The installed capacity in the power plants of the National Power System (NPS) is $24,555 \mathrm{MW}$ while the available power on 2015/04/01 was 22,308 MW.

The total installed capacity at the end of year 2014 in units of electrical energy production from renewable energy sources (RES-E) is $4747 \mathrm{MW}$.

The structure of the installed power in RES-E (wind power plants, photovoltaic power plants, hydroelectric power plants with an installed capacity that is not larger than 10 MW, biomass power plants) is presented in Figure 1.

The evolution of the RES-E installed capacity and implicitly of the investments in renewable energy sources, starting in year 2007, is presented in Figure 2. There is an increase of investments in generation capacity of electrical energy from renewable energy sources, especially wind power and solar power, following the implementation of the support scheme through green certificates and mandatory annual quota.

The contribution of the renewable energy sources (exclusively hydro) to the production of electricity in Romania has had a value of $11.02 \%$ (Fig. 3).

\section{The mandatory quota and green certificate system in Romania}

As a member of the EU, Romania has assumed through the Accession Treaty a number of targets concerning the share of the green energy it will have in electricity consumption at the end of year 2020 . 

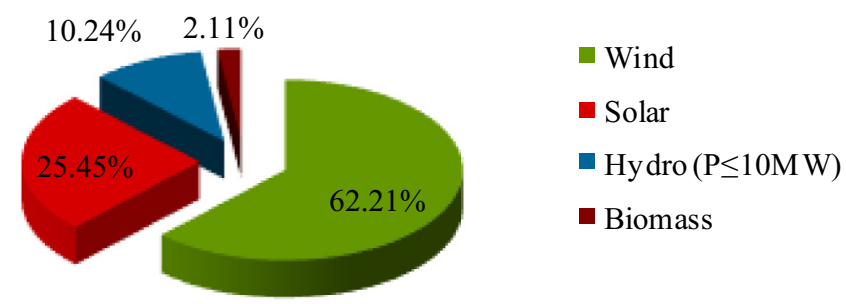

Fig. 1. The installed power structure of RES-E in the year 2014. Data processed from website: http://www.transelectrica.ro [10].

For encouraging and supporting the production of electrical energy from renewable energy sources, it was conceived a set of rules which is based on the existence of green certificates and a mandatory quota system, system where by the electrical energy suppliers are forced to buy, in a certain amount, electrical energy produced from these sources to sell it to consumers.

For this combination, the amount of electrical energy is established by the government and the price of green certificates by market. For every unit of electrical energy produced from renewable energy sources $(1 \mathrm{MWh})$ delivered in the network, producers receive a number of green certificates that depends on the technology utilized, which can be sold, separately from the electrical energy produced, on the green certificates market (Table 1).

The green certificate market is distinct from the electricity market which is dependent on competitive mechanisms, respectively on the supply and demand of green certificates. The trade of green certificates is done, in a competitive system, on the bilateral contracts market and/ or the centralized green certificates market (monthly), between the producers of RES-E and the electricity suppliers to final consumers and is not restricted by the associated trading of electrical energy. The number of green certificates a supplier needs to meet the mandatory quota by acquisition of green certificates in a given year must be equal to the product between the annual mandatory quota value and the amount of electricity supplied to serve consumers.

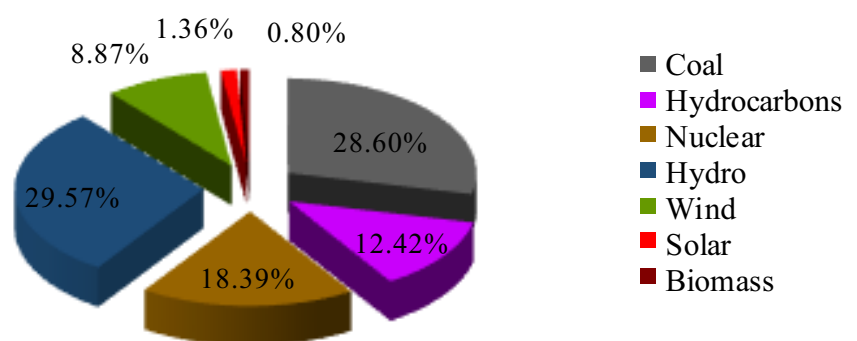

Fig. 3. The structure of electricity production in 2014. Data processed from website: http://www.transelectrica.ro [10].

For the year 2014, the quota of green certificates achieved by the Romanian Energy Regulatory Authority is equal to $0.218 \mathrm{GC} / \mathrm{MWh}$. The evolution of legally established quotas of green certificates and the quotas that were achieved by acquisition of green certificates by suppliers, between 2007 and 2014, is presented in Figure 4.

The annual RES-E quota that was achieved between 2007 and 2011 was lower than the annual quota legally established, in the year 2012 it was very close to the mandatory annual quota and in the year 2013 it exceeded the annual mandatory quota.

The electricity price development and the number of certificates traded on the green certificates market is presented in Figure 5. There is a tendency to reduce the price of green certificates due to the increasing number of traded green certificates.

\section{Conclusions}

The mandatory quotas system combined with the trade of green certificates is a system that is compatible with the competitive market and promotes the usage of renewable energy sources.

Following the implementation of the support scheme through green certificates and mandatory annual quotas in Romania, in recent years there have been significant

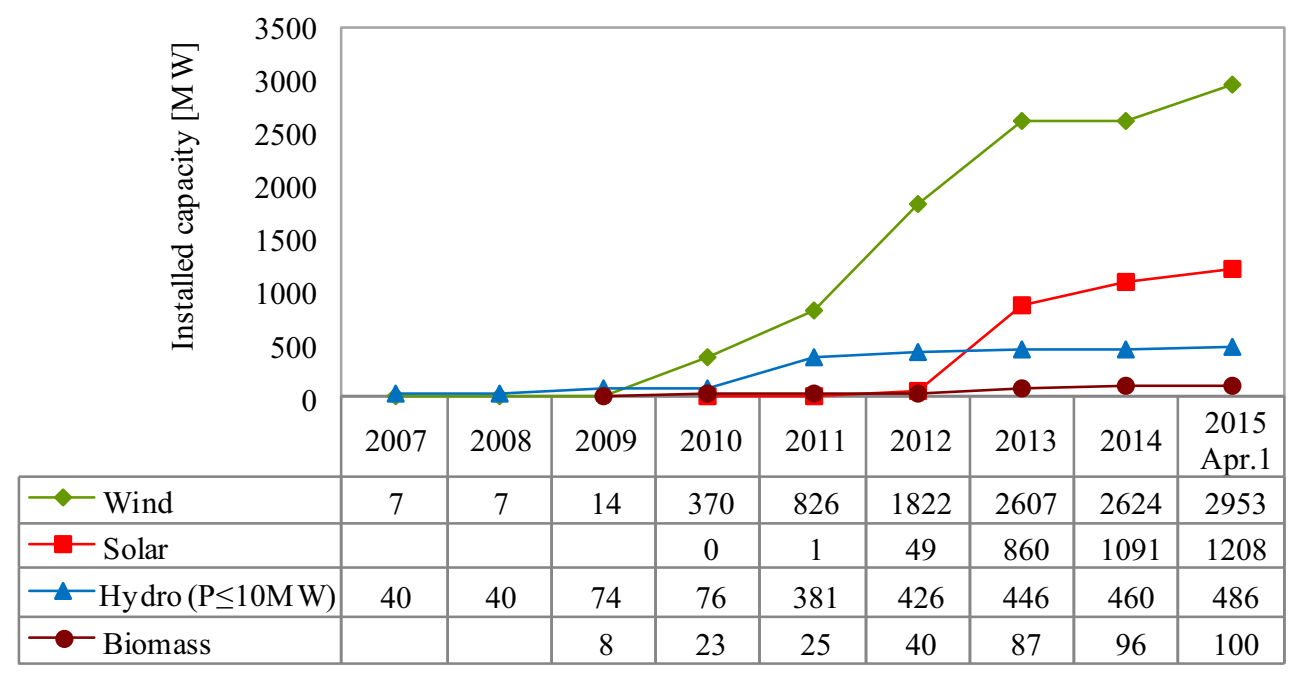

Fig. 2. The evolution of the RES-E installed capacity. Data processed from website: http://www.transelectrica.ro [10]. 
Table 1. The promotion system of RES-E in Romania.

\begin{tabular}{|c|c|c|c|c|}
\hline SRE type & $\begin{array}{l}\text { Type of power } \\
\text { plant/group }\end{array}$ & $\begin{array}{l}\text { Number of } \\
\text { GC/MWh }\end{array}$ & $\begin{array}{l}\text { Delay (OUG 57/2013) } \\
2013 / 07 / 01-2017 / 03 / 31\end{array}$ & HG 994/2013 \\
\hline \multirow{3}{*}{$\begin{array}{l}\text { 1. Hydraulic energy- } \\
\text { used in power plants } \\
\text { with installed power } \\
\leq 10 \mathrm{MW}\end{array}$} & New & $3 \mathrm{GC}$ & $1 \mathrm{GC}$ & Reduction 0.7 GC \\
\hline & Upgraded/refurbished & $2 \mathrm{GC}$ & - & - \\
\hline & Not upgraded & $0.5 \mathrm{GC}$ & - & - \\
\hline \multirow[t]{2}{*}{ 2. Wind energy } & New & $\begin{array}{l}2 \text { GC until } \\
2017\end{array}$ & $1 \mathrm{GC}$ & $\begin{array}{l}\text { Reduction } 0.5 \text { GC } \\
\text { until } 2017\end{array}$ \\
\hline & & $\begin{array}{l}1 \mathrm{GC} \text { as of } \\
2018\end{array}$ & - & $\begin{array}{l}\text { Reduction } 0.25 \text { GC } \\
\text { as of } 2018\end{array}$ \\
\hline \multirow{2}{*}{$\begin{array}{l}\text { 3. Biomass, biogas, } \\
\text { landfill gas, bio- } \\
\text { liquid, geothermal }\end{array}$} & New & $2 \mathrm{GC}$ & - & - \\
\hline & $\begin{array}{l}\text { High efficiency } \\
\text { cogeneration (additional } \\
\text { to the } 2 \text { GC) }\end{array}$ & $1 \mathrm{GC}$ & - & - \\
\hline 4. Solar energy & New & $6 \mathrm{GC}$ & $2 \mathrm{GC}$ & Reduction 3 GC \\
\hline
\end{tabular}

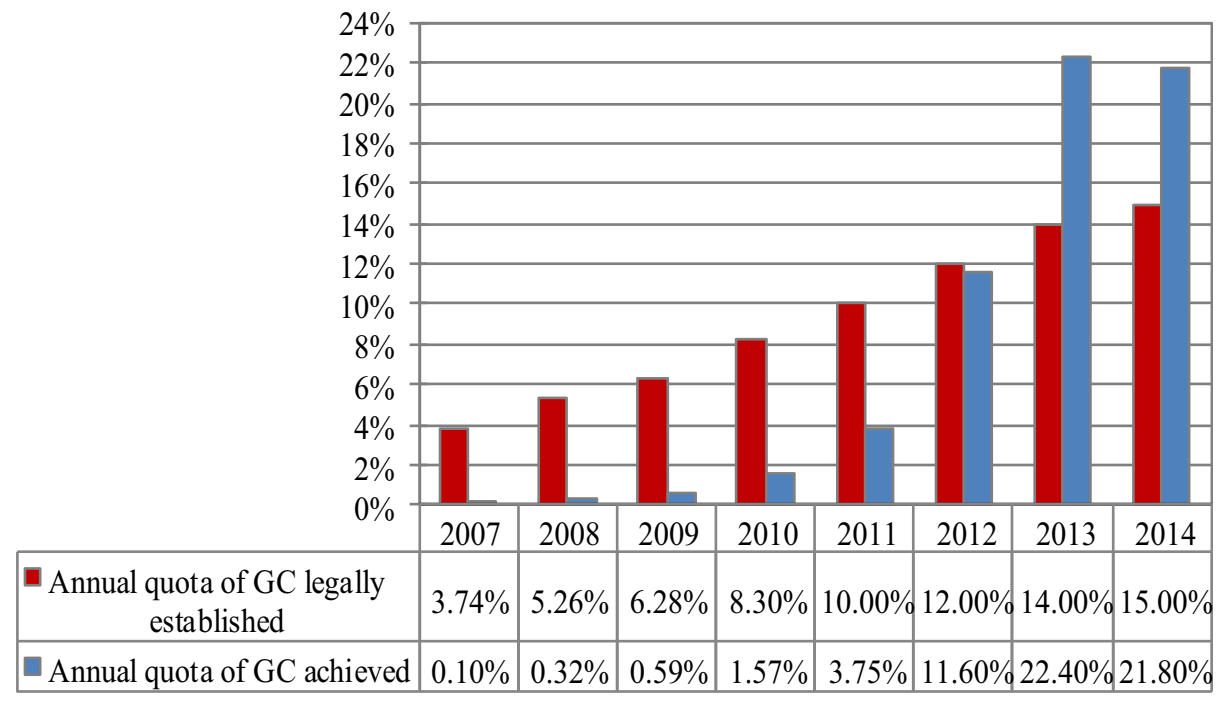

Fig. 4. The annual mandatory quotas of GC purchase and those achieved for the 2007-2014 period. Data processed from website: http://www.transelectrica.ro [10] and http://www.anre.ro [11].

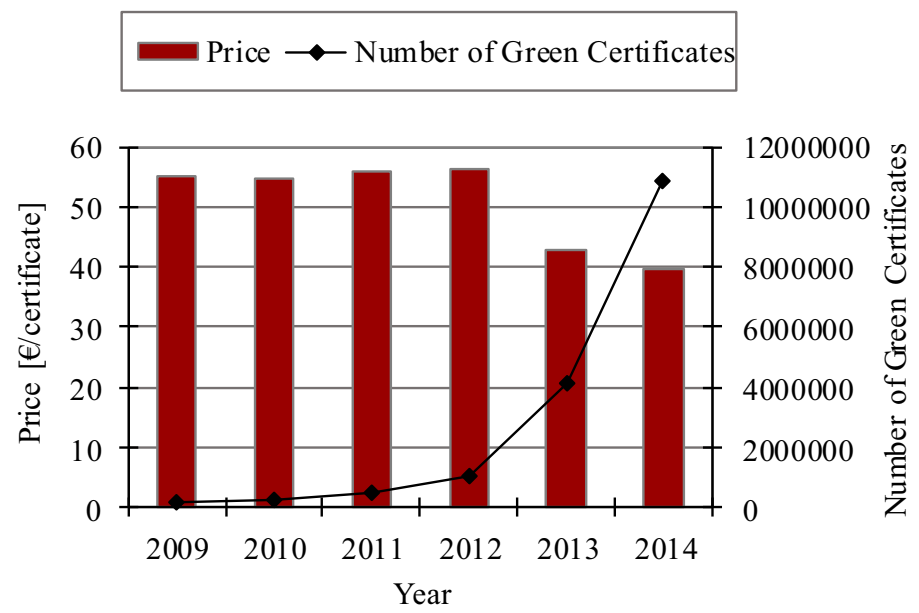

Fig. 5. Electricity price development and the number of certificates traded on the Green Certificates Market. Data processed from website: http://www.opcom.ro [9]. 
increases of investments in production capacities of electrical energy from renewable sources, especially wind power and solar power.

Currently, we can see a lowering in investment costs over the estimated costs at the time when the support schema was conceived. The lowering of the specific investment is due to the technological evolution in this field. To avoid overcompensation, was necessary lowering the number of green certificates established by law for every category of RES-E producers.

The authors acknowledge financial support from the project Integrated Center for Research, Development and Innovation in Advanced Materials, Nanotechnologies, and Distributed Systems for Fabrication and Control, Contract No. 671/09.04.2015, Sectoral Operational Program for Increase of the Economic Competitiveness co-funded from the European Regional Development Fund.

\section{References}

1. A. Poullikkas, G. Kourtis, I. Hadjipaschalis, An overview of the EU Member States support schemes for the promotion of renewable energy sources, Int. J. Energy Environ. 3, 553 (2012)
2. R. Haas, G. Resch, C. Panzer, S. Busch, M. Ragwitz, A. Held, Efficiency and effectiveness of promotion systems for electricity generation from renewable energy sources e Lessons from EU countries, Energy 36, 2186 (2011)

3. J. Canton, A.J. Linden, Support schemes for renewable electricity in the EU (European Commission, DirectorateGeneral for Economic and Financial Affairs, Brusseles, 2010)

4. M. Ragwitz, A. Held, G. Resch, T. Faber, C. Huber, R. Haas, Monitoring and evaluation of policy instruments to support renewable electricity in EU Member States (Institute Systems and Innovation Research Fraunhofer, 2006)

5. M. Ringel, Fostering the use of renewable energies in the European Union: the race between feed-in tariffs and green certificates, Renew. Energy 31, 1 (2006)

6. J. Lipp, Lessons for effective renewable electricity policy from Denmark, Germany and the United Kingdom, Energy Policy 35, 5481 (2007)

7. A. Ford, K. Vogstad, H. Flynn, Simulating price patterns for tradable green certificates to promote electricity generation from wind, Energy Policy 35, 91 (2007)

8. L. Nielsen, T. Jeppesen, Tradable Green Certificates in selected European countries: overview and assessment, Energy Policy 31, 3 (2003)

9. Romanian Power Market Operator: http://www.opcom.ro

10. Romanian Power Grid Company: http://www.transelectrica. ro

11. Romanian Energy Regulatory Authority: http://www.anre.ro

Cite this article as: Pavel Atănăsoae, Radu Pentiuc, Crenguţa Bobric, Eugen Hopulele, The evolution of the support scheme for promoting renewable energy sources in Romania, Renew. Energy Environ. Sustain. 1, 27 (2016) 